\title{
Patient Advocacy History, Evolution and Impact on Health
}

\author{
Ana Rita Gonzalez* \\ President and CEO of Policy Wisdom LLC, Miami, Florida
}

Submission: April 25, 2018; Published: April 30, 2018

*Corresponding author: Ana Rita Gonzalez, President and CEO of Policy Wisdom LLC, 11423 SW 87th Terrace, Miami, Florida, Tel: +1-305-456-5443; Email: argonzalez@policywisdom.com

\begin{abstract}
An analysis behind the concept of advocacy reveals not only a myriad of definitions and explanations related to patient advocacy, beyond a pleader for the vulnerable or watchdog, but also attributes and roots that go back all the way from the Ming Dynasty to its American birth in the 1920 's, and more recently as an egalitarian human rights tool. A brief rich historical tradition serves as a background to put into perspective the reason behind the birth, evolution and growth of advocacy until its current important role in influencing health, not only in the United States, but as a global growing movement. This historical perspective adds to prior related research of the author on the concept and vision behind health equity. But there is more behind the meaning and history of these two intertwined terms as impactful to health, equality and basic human dignity but, most importantly, as able to amplify the voice of one, or many.
\end{abstract}

Keywords: Patient advocacy; Human rights; Group advocacy; Equality; Patient's Bill of Rights; History; HIV/AIDS grassroots; International Patient Advocacy Framework (IPAF); International Alliance of Patients' Organizations (IAPO)

Abbreviations: IAPO: International Alliance of Patients' Organizations; ANA: American Nurses Association; FDA: Food and Drug Administration; IPAF: International Patient Advocacy Framework; HIV: Human Immunodeficiency Virus; AIDS: Acquired Immune Deficiency Syndrome; JAHCO: Joint Commission on Accreditation of Healthcare Organizations

\section{Introduction}

Health equity and patient advocacy are concepts that nurture each other, are catalytic of change and have a rich historic perspective. Prior original research about the historical analysis of health equity published by the author in 2017 concluded that, beyond its meaning, a significant step forward lies in articulating the policies and practices that can lead us toward the ideal of health equity, and in being able to summon the social commitment and political will to turn vision into reality. The same is true for patient advocacy.

Descriptions of the 'advocate' term range from counselor, watchdog and representative, to potential whistleblower as well as a pleader for the vulnerable. Advocacy types provide a kaleidoscope into every aspect of human nature including legal, human, system, individual, political, legislative, spiritual, moral-ethical and patient advocacy. There does appear to be a consensus that advocacy involves one person representing another. However, for Archer L. it means more than speaking for another as it involves intervention for 'vulnerable' people who require it [1]. The results from the analysis of the concept of advocacy reveal that it is a combination of three essential helping strategies. Only when valuing, apprising and interceding are combined can advocacy be realized. Advocacy involves enabling patients to make their own decisions regarding health care, which will encourage the likelihood of them obtaining the health care of their choice. The final attribute is interceding. It means coming between parties and intervening or mediating where necessary [2].

\section{Discussion}

Part of advocacy's rich historic tradition had its origins in bureaucratic movements aimed at working toward the benefit of individuals. In the $14^{\text {th }}$ century the Ming Dynasty has the first mention of a government ombudsman - "one who acts on behalf of another" [3]. Later in the 1920's nurses played a key role in promoting the rights of patients in their Code of Ethics [4], and during WWII Great Britain established a Citizen Advice Bureau. But it wasn't until the 1970's that a formalized patient advocacy program development emerged in healthcare [3]. While the term "patient advocacy" is more recent, its roots are in the much "broader field of public health education that became a social force beginning in the 1900 's." Clarence Pearson, a public health educator who worked at MetLife for much of his career, established the first organized, private sector public health education program in the United States [5]. In 1926, the ANA, presented a nursing Code of Ethics that established the goals, values and obligations of this profession. The Code of Ethics includes nine provisions; particular to this research is provision three that includes the statement: The nurse promotes, advocates for, and strives to protect the health, safety, and rights of the 
patient [4]. While patient advocacy groups, in their current form, began from the early days of cancer research and treatment in the 1950 's, one, if not the best-known, example comes from the very roots of patient engagement in the HIV/AIDS grassroots advocacy of the 1980s. This work evolved in the 90's with the FDA's Patient Representative Program, which today includes over 300 diseases and conditions [6]. In reaction to a medicalcentric perspective during the 1960's, patients' rights advocates and organizations began to establish themselves in the early 70's out of patient self-help and self-care movements [7]. In the early 1970's, hospitals began to recognize the need for a liaison between patients and hospitals [3]. In the 70's and 80's the concept of the empowered patient-consumer arose and was embraced by activists to redress the growing imbalance of power between patients. and care givers in order to ensure that the patients came before the profits.

\section{The Evolution of Patient Advocacy}

Patient advocacy groups started out as support and selfhelp groups, joining those who have a common illness/disease to assist those who are diagnosed and who have survived. Following an outburst of patient activism, which was highly informed and motivated, the pharmaceutical industry and regulators were forced to reconsider the way they interacted with patients. Today there are many patient advocacy groups, and these are increasingly more involved in the pharmaceutical, regulatory and policy-making process. The current field of patient advocacy has its roots in the patient rights movement of the 1970's including the American Cancer Society, March of Dimes and Margaret Sanger, precursor of Planned Parenthood. The National Welfare Rights Organization was instrumental in getting a patient bill of rights accepted by JACHO in 1972. That document is the foundation for patient rights and advocacy today [7]. In 1998 the U.S. Advisory Commission on Consumer Protection and Quality in the Health Care Industry adopted the Consumer Bill of Rights and Responsibilities, commonly known as the "Patient's Bill of Rights." It stresses the importance of a healthy relationship between the healthcare provider and the patient and plays a key role in outlining all the rules, regulations and stipulations on the part of the healthcare provider when dealing with all patients $[3,9]$. Human rights advocacy strategies include sensitization, participation, protection, good governance, and accountability [10].

\section{The Growing Global Movement: The First Big Accomplishments of Patient Advocacy}

One of the primary results of patient advocacy was that the FDA created an office to work with patient advocates. This work in particular has evolved in the 90's with the Patient Representative Program, which solicits the involvement of patients to inform the regulatory decision-making process through advisory committees and panels. Today, this program now includes over 300 diseases and conditions [6]. Patient advocacy groups have evolved to not only include support and serve as clinical liaisons, but also focus on education, public policy as well as advocacy to serve the increasingly more complex global healthcare systems. In fact, currently the IAPO, works to promote patient-centered healthcare around the world. It currently has 276-member organizations from 71 countries representing 50 disease areas [11].

\section{Conclusion}

From a historical perspective, in the mid-1900s patient advocacy groups arose from self-help groups, organized from natural "support systems" of patients and their involvement in learning and contributing to decisions about their own destiny [7]. That destiny is now rich, relevant, diverse and global, reaching from patient advocacy, to regulatory and policy influence, to self-empowerment. Patient advocacy and cultural awareness education must continue to gain momentum in today's healthcare environments and curricula. Healthcare leaders that embrace and deliver these important interventions will observe higher patient satisfaction scores and lower health disparity rates among all populations within their communities [4]. The advocate's role in today's changing healthcare environment continues to evolve. With a heightened awareness of the importance of a positive patient experience, many improvement initiatives are currently underway in hospitals. The patient advocate role is a critical part of these efforts. From a regulatory perspective, the patient advocate is often responsible for oversight of the organizations' compliance with patient rights, administration of the language services program, management of the complaint and grievance processes and identification of improvement opportunities through the analysis of data gathered within the process of addressing complaints and grievances [3]. The IPAF is globally relevant and could be adapted and implemented in other countries to amplify patient voices in the policymaking process, increase grassroots mobilization, improve health systems through addressing patient needs, and ultimately support countries in meeting health targets for infectious and non-communicable diseases, from access to prevention, to treatments, rehabilitation and cures. Further research is also needed on the long-term impacts of patient advocacy [12]. Societal and government commitment is needed to support the patient voices with resources and the formal opportunities that allow the advocacy groups to deliver on their mission. Furthermore, the policy making process must require the involvement of patient advocacy to ensure that decisions are made with the interests of patients properly reflected. Experts state that ultimately, the benefits of collaboration in advocacy include "a reduction in redundancy of services, conservation of human and financial resources... and population of survivors who are empowered and engaged advocates".

\section{Acknowledgement}

Our gratitude to all who bravely spoke on behalf of others, setting the irrevocable and constant path for patient advocacy from its humble beginnings in China until today, as it reaches a global stage and impacts communities close and afar. 


\section{Juniper Online Journal of Public Health}

\section{Refernces}

1. Archer Copp L (1986) The nurse as advocate for vulnerable persons. Journal of Advanced Nursing 1: 255-263.

2. Baldwin MA (2003) Patient advocacy: a concept analysis. Nursing Standard 17(21): 33-39.

3. Clarke K, Pedersen K, Santalucia C (2015) Patient Advocate: A Critical Role in Patient Experience. The Beryl Institute, USA.

4. Ronnebaum ED, Schmer C (2015) Patient Advocacy and the Affordable Care Act: The Growing Need for Nurses to Be Culturally Aware. Open Journal of Nursing 5: 237-245.

5. Earp JA, French EA, Gilkey MB (2008) Patient Advocacy for Health Care Quality: Strategies for Achieving Patient-Centered Care.

6. Clariness A short History of Patient Centricity.
7. Katz AH, Bender EI (1976) Self-help groups in Western society: History and prospects. The Journal of Applied Behavioral Science 12(3): 265282.

8. (2010) The Principle and Brief History of Patient Advocacy. Healthcare Whisperer.

9. (2011) The Patient's Bill of Rights (and the Advocate's Role) Profesional Patients Advocate Institute (PPAI).

10. Pavlish C, Ho A, Rounkle AM (2012) Health and human rights advocacy: perspectives from a Rwandan refugee camp. Nurs Ethics 19(4): 53849.

11. International Alliance of Patients' Organizations.

12. Schear RM (2015) International Framework for Cancer Patient Advocacy: Empowering Organizations and Patients to Create a National Call to Action on Cancer. J Glob Oncol 1: 83-91.

\section{Your next submission with Juniper Publishers} will reach you the below assets

- Quality Editorial service

- Swift Peer Review

- Reprints availability

- E-prints Service

- Manuscript Podcast for convenient understanding

- Global attainment for your research

- Manuscript accessibility in different formats

(Pdf, E-pub, Full Text, Audio)

- Unceasing customer service

Track the below URL for one-step submission https://juniperpublishers.com/online-submission.php 